\title{
The Multiple Geographies of Peterloo and Its Impact in Britain
}

\author{
KATRINA NAVICKAS, UNIVERSITY OF HERTFORDSHIRE
}

\begin{abstract}
The Peterloo Massacre was more than just a Manchester event. The attendees, on whom Manchester industry depended, came from a large spread of the wider textile regions. The large demonstrations that followed in the autumn of 1819, protesting against the actions of the authorities, were pan-regional and national. The reaction to Peterloo established the massacre as firmly part of the radical canon of martyrdom in the story of popular protest for democracy. This article argues for the significance of Peterloo in fostering a sense of regional and northern identities in England. Demonstrators expressed an alternative patriotism to the anti-radical loyalism as defined by the authorities and other opponents of mass collective action.
\end{abstract}

Keywords: Peterloo; Manchester; protest; radicalism; regional identity

The Peterloo Massacre and its aftermath in the political history of nineteenth-century Britain has left historians with a wealth of textual and visual evidence. Newspaper reports, printed accounts of the trials of the radical leaders and autobiographical recollections such as those of Samuel Bamford, and vivid caricatures drawn by George Cruikshank have formed the basis of scholarly and public analysis of the causes and impact of the events of 16 August 1819. ${ }^{1}$ More recent interest in the cultural history of popular politics in this period has also drawn from the wealth of printed material, including radical poetry and the satire of William Hone. ${ }^{2}$ In terms of its spatial context, the Peterloo Massacre is indelibly associated with the specific place in which it occurred: St Peter's Fields on the southern edge of the rapidly expanding centre of industrial Manchester. Both contemporaries and later scholars have pored over the various printed plans of the position of the troops, magistrates and crowds to unpack the contradictory accounts of exactly where and how the yeomanry cavalry went to get to the hustings. ${ }^{3}$

Peterloo also represented the towns and villages from which processions marched, the textile districts to the north and east of Manchester. Michael Bush has mapped out the residences of the casualties to show how the meeting attracted a significant proportion of the working population of this region. ${ }^{4}$ Robert Poole and Malcolm Chase have furthermore placed the processions of the radical societies within the rich context of popular folk custom and working life of the textile districts of the region. ${ }^{5}$

This article examines the wider geographies of Peterloo. It calls on historians to consider the event through different spatial levels, stretching from the microlocal to the regional to the national. Peterloo was not solely a local incident. The demonstrations that followed in the autumn and winter of 1819 in protest at the actions of the magistrates, yeomanry and government were first regional and then national, establishing the massacre as a nationally significant event and firmly part of the radical canon of martyrdom in the story of democracy. This article argues for the 
important impact of Peterloo in fostering a sense of regional and indeed northern identity in England, as well as being a continual reference point for national political movements in the nineteenth century.

\section{From the Local to the Regional}

Popular radicalism drew its strength from the local. The Hampden clubs and female reform societies that formed in the aftermath of the Napoleonic Wars were locally based in districts of the industrial towns of the North and Midlands. They drew from the organisation of friendly and trades societies and Methodist class meetings, while the 'Sunday best', ribbons and laurels worn, and banners carried in the processions consciously reflected the customary traditions of weaving and mining villages, especially the rushbearing processions of the southern Pennines. ${ }^{6}$

The geography of the known participants at the meeting and the victims of Peterloo indicate the tight bonds of neighbourhood that were formed in Manchester and the surrounding industrial towns and villages in this period. Families, workmates and other close communities marched together and stuck together on St Peter's Fields, in a strong demonstration of very localised identities. The locales of Angel Meadow, New Cross and Ancoats to the north of Manchester contained a particular concentration of independent-thinking artisans, handloom and powerloom weavers and other textile workers who left at least some trace in the annals of democratic radicalism and trade unionism. Out of the eleven names of radical leaders who signed the first requisition for a public meeting to be held on 9 August at St Peter's Fields, only one, the letterpress printer William Ogden, lived outside Ancoats (on Wood Street, off Deansgate). The other ten all lived in a tightly defined area within a few streets north and south of Great Ancoats Street. ${ }^{7}$ Their homes were within 0.2 miles of the New Cross junction, which was a central meeting point for many processions and gatherings of people coming into the centre from north Manchester and beyond, and within 0.1 miles, that is, easy walking distance, from each other. Notably also, the Manchester Observer office was central to this locale, being at 49 Great Ancoats Street, and the meeting rooms of the Manchester Union Society were also located in this area, on George Leigh Street. ${ }^{8}$

On a regional level, the casualty lists indicate that the attendees at the Manchester meeting were drawn predominantly from the towns and villages that formed the spokes of the wheel of roads leading into Manchester, from Bolton in the north, then eastwards through Bury, Rochdale, Oldham and Saddleworth, Ashton-under-Lyne to Stockport in the south. No victims or banners were recorded in the press for Wigan, Leigh or Warrington, although there was evidence of radical societies having been formed in those areas. All the contributing towns and villages faced the Pennines, had strong communities of handloom weavers facing hardship in the economic circumstances following the end of the war, and rich traditions of collective action and custom. ${ }^{9}$

Yet localism could coexist with a desire for connection to the wider 'mass platform' radical movement. The desire of the new working-class radical groups for political 
redress for the economic condition of the nation through parliamentary reform connected them together in a wider movement that went way beyond local grievances. In the eighteenth century, the solution to poverty was often sought locally, by seeking redress from local landowners or through their representation to Parliament, or more directly through food rioting. But following the American and French revolutions, the message that popular radicals drew from their readings of Thomas Paine and Major Cartwright was of one of universalism; that they could influence the state of the nation directly by addressing the Prince Regent and petitioning Parliament directly for a change in the representative system as a solution to their poor condition. Charles Tilly argued for a shift in the 'repertoires of contention' in this period between the insular localism of food riots to the new social movements' determination to seek direct political redress from Parliament. ${ }^{10}$ His binary between eighteenth- and nineteenth-century forms of protest reaching a turning point in 1819 is somewhat too stark and deterministic, as many forms of customary action continued well into Chartism in the 1840 s and the reform agitation of $1867 .{ }^{11}$ Yet Tilly's identification of a broader shift nevertheless highlights the novelty and agency of the working-class democratic movement's appeal to national authorities. Peterloo encapsulated the powerful combination of local with national and universal.

The meeting on St Peter's Fields had been set up as nationally significant for the mass platform movement. The actions of the magistrates and yeomanry made it immediately into a recognisable turning point in elite attitudes to working-class collective action. The government's dealings with the Manchester magistrates in the lead-up to 16 August had already ensured that it was more than just a local event. As Robert Poole has powerfully argued, and Nathan Bend considers again in this volume, the instruction from under-secretary of state Henry Hobhouse to James Norris, boroughreeve of Manchester, on 16 June, that 'if the Magistrates shall see an opportunity of acting with Vigour, they will recollect that there is no situation in which their Energy can be so easily backed by Military aid as at Manchester, where the Troops are at hand' indicated the government's assent to suppression of the radical movement by the 'sword' as well as by 'the law'. ${ }^{12}$ It also indicated how Manchester was seen by the government as the centre of the democratic movement by 1819 . London radicalism, which had been the cauldron of the corresponding society system and republicanism since the 1790s, had lost its direction of purpose and popularity to the more organised union system in Lancashire and Yorkshire. The local authorities in London were perturbed by the Spa Fields mass meetings organised by the republican followers of Thomas Spence that ended in riot in the winter of 1816-17, and the more recent mass platform demonstration addressed by Henry Hunt at Smithfield on 21 July 1819.

The minute book of the Newington petty sessions reveals the impact of the reform meetings and response to Peterloo upon the authorities and public in London. Most entries in the volume covering 1810-19 concern the humdrum business of licensing public houses. Then suddenly in August 1819, a series of special meetings were held by the magistrates of East Brixton and Southwark to discuss policing the proposed reform meetings to be held at Smithfield and Kennington Common. On 11 August, 
the magistrates sent a deputation to the Home Office to request military assistance for a planned meeting on Kennington Common on 23 August. Lord Sidmouth agreed to provide them with sufficient police officers and noted that the intended meeting 'had already attracted the attention of His Majesty's Ministers'. ${ }^{13}$ This note provides extra context for the decision making of the Home Secretary and the government in the days leading up to Peterloo. Sidmouth's focus was not just on Manchester; he was clearly being pressed by authorities from across the country, including in London, about what they regarded as potentially seditious situations on his doorstep. The East Brixton magistrates, however, did not appear to have been asking Sidmouth for permission to suppress the reform meetings, unlike the Manchester magistrates who were much more assertive in calling for military action.

The public meetings held by northern radicals, especially at Sandy Brow in Stockport and Hunslet Moor in Leeds, were anxiously reported by the local magistrates to the Home Office, and became Sidmouth's main concern. ${ }^{14}$ Henry Hunt's position as the lead orator and therefore the main attraction on the hustings focused national attention on the upcoming Manchester meeting, especially after it was postponed by the radical committee for a week to ensure its procedures remained within the bounds of legality. Radical and anti-radical press also amplified the geographical reach in anticipation of Monday 16 August. The London publisher and republican Richard Carlile travelled up from Birmingham on the Saturday, joining Henry Hunt at his lodgings at Smedley Cottage on the Sunday. Two London reporters were present on the hustings - The Times's John Tyas and The Courier's Charles Wright, invited by Joseph Johnson to sit on the platform to record the constitutional and peaceful intentions of the speakers. The sense that they had witnessed an injustice of a magnitude much greater than seen before was clearly evident and spread quickly. ${ }^{15}$ Tyas, who had been attacked on the hustings, wrote a report in The Times condemning the authorities, which was published on 19 August. The report was certainly a factor in raising mass public awareness of Peterloo across the country. ${ }^{16}$

The immediate response to Peterloo was lockdown and panic among the authorities and loyalist inhabitants. Reformer Absalom Watkin recalled in his diaries that on 17 August, the Manchester magistrates, fearing further processions coming in from Oldham and elsewhere, gave orders 'to close all shops and warehouses and to clear the streets of carts and all obstructions'. As they assembled the military, 'a state of confusion and hurry and dismay, truly ridiculous, took place. People ran about as if the pikes had been close behind them and most people left their warehouses and went home'. ${ }^{17}$ Watkin's account and other reports suggest that heightened anxiety created an exceptional situation fuelled by rumour and fear. The constables of Manchester Police Office claimed that on the afternoon of 17 August, '[Robert] Campbell, one of our supernumeraries ... was literally stoned to death, publicly ... merely because he was connected with this office', and that the boroughreeve and constables, when arriving at Newton Lane to suppress the agitation, 'were also violently attacked and beaten away with stones previously taken up from the pavement for the purpose' ${ }^{18}$ The police constables and the newspapers alleged that working-class districts around Oldham Street and New Cross in Manchester became 
no-go areas for anyone associated with the forces of law and order for well over a month after Peterloo. ${ }^{19}$ These accusations were a slur made by the loyalist elites in an attempt to prove that the working classes who attended the 16 August meeting had been armed and intent on insurrection, but there is evidence of increased tension and political division that spilled into harassment and violence on both sides. Peterloo stoked up existing tensions, breaking out into violence and pitting groups against one another.

This unrest was not just confined to Manchester and its surrounding towns where connection to the events of 16 August could be personal and direct; suspicion and a desire for vengeance on both sides extended well beyond the immediate region. Following a reformers' meeting in Macclesfield marketplace on 17 August, the properties of those suspected of supporting the Manchester magistrates were attacked, including the printer of the Macclesfield Courier, an officer in the Cheshire yeomanry cavalry, the postmaster, the town clerk, several prominent silk and cotton manufacturers and the headmaster of the grammar school. ${ }^{20}$ Personal attacks continued into $1820 .^{21}$ The coachman of Reverend Charles W. Ethelston, one of the Manchester magistrates, was attacked at Bank Top, on 10 October 1819, allegedly by 'a party of radicals in grey hats' ${ }^{22}$ The personal and party divisions exposed by Peterloo ran deep and long, and periodically continued to break out into violence.

While the 'general risings' organised by radicals in Huddersfield and Barnsley in April 1820 were the most physical and militant expressions of discontent at the suppression of the popular reform movement, a general undercurrent of suspicion and agitation continued on a more quotidian and personal level. In the same month as the Yorkshire risings, for example, newspapers also reported a fight between five privates of the 7th Dragoon Guards and local inhabitants in an Oldham pub, allegedly caused after radicals raised 'disloyal' toasts and sang the ballad 'The Peterloo Massacre'. ${ }^{23}$ Radical leaders, fearing further suppression, sought to channel these outbreaks of agitation into peaceful demonstrations, but the line between the two was always thin.

News of the event was also spread through oral reports from people riding the stagecoach network. Anne Lister of Shibden Hall described the news arriving over the Pennines in Halifax the same evening by the mail coach. ${ }^{24}$ The narrative of Peterloo was developed and publicised further by three of the Manchester radical leaders, John Knight, Joseph Mitchell and John Thaxter Saxton, who undertook the deliberate tactic of a tour around south Lancashire and the West Riding in the autumn of $1819 .^{25}$ The wave of protest demonstrations by reformers against the actions of the magistrates and in support of the Peterloo victims began with hastily organised gatherings and demonstrations in the immediate aftermath, followed by bigger demonstrations in September and October, culminating in mass commemorations organised by the radical union societies in a semi-coordinated programme between 1 and 8 November 1819. Many of these meetings were organised locally by the 'reformers on the radical or union system' who attempted to follow due process in calling a public meeting by waiting on the mayor of the town with a requisition from 'respectable' householders. Mostly, the local authorities would not hold the meetings 
in response to the requisitions, but nevertheless gave assurances that they would not suppress them as long as they were conducted peacefully. ${ }^{26}$ The authorities' permissive attitude may have stemmed from the uncertainty created in the aftermath of Peterloo over the legality to shut down public meetings.

In response to Peterloo, the reform committees in London convened a meeting on Saturday 21 August at the Crown and Anchor pub on the Strand, the traditional headquarters for radical groups since the London Corresponding Society in the 1790s. The committee included Major John Cartwright, the satirist T. J. Wooler and the Sheffield printer John Gale Jones. John Hockley was arrested on the day for standing outside the pub holding a placard advertising the meeting. The law officers recommended a quarter sessions indictment for inciting disturbance. ${ }^{27}$ The shoemaker Samuel Waddington took the chair, and in his opening speech proclaimed that, 'even in the worst period of the American revolution, at which he was present, he never heard such outrages'. ${ }^{28}$ Iain McCalman has mapped out the various factions within the London reformers; some following Spence and Wedderburn were seeking revolution, while others favoured moderation. ${ }^{29}$ Indeed, Major Cartwright refused to support the next proposed public meeting at Smithfield on 25 August, which was addressed by the Spenceans who had organised the Spa Fields meetings, Dr James Watson, Arthur Thistlewood and Thomas Preston. The Surrey magistrates again waited upon the Home Office, meeting Henry Hobhouse on 23 August to request military support. The Smithfield meeting was heavily policed, with 150 police, 500 special constables and 500 East India Company constables on standby. ${ }^{30}$ The magistrates held a special meeting on the day of the public demonstration, sending spies to report back to them, noting in the minute book that the crowd 'behaved very orderly and at last dispersed quietly'. ${ }^{31}$

The different levels of geographical identity expounded by the radicals was indicative of their universalism, at least in their rhetoric if not in reality. Significantly, the Smithfield meeting was advertised as 'a public meeting of the British Metropolis, on behalf of the People of the whole Empire'. ${ }^{32}$ By using this phrase, the London radicals clearly envisaged themselves representing national popular opinion, although their claim was illustrative of the age-old attempts at metropolitan dominance. Further protest meetings took place in the autumn of 1819, reaching a climax in November before the passage of the 'six acts' through Parliament that heavily restricted such political gatherings. Significantly, the demonstrations were held across the industrial North and Midlands, from Manchester, Carlisle, Newcastle, Halifax, Huddersfield, Leeds, Bolton, Newcastle, Dewsbury, Barnsley, Otley, Nottingham, Leicester to Coventry among other places. ${ }^{33}$ The range of places is testimony to the extent of radical unions or committees, but also a wider popular movement that was engendered or at least invoked to act in response to the injustice at Manchester. E. P. Thompson noted the electrifying impact of news of Peterloo particularly among the pitmen of Northumberland and Durham, where the whole district seemed to turn over to the reformers'.

Following a mass meeting at Newcastle Town Moor on 11 October, reputedly attended by 25,000 people, the city and its surrounding pit villages and ports fostered 
radical classes, which sustained a tradition of popular constitutionalism right through to Chartism in the 1840s. ${ }^{34}$ Popular pamphlets illustrated the change of sentiment. 'Radical Monday: a Letter from Bob in Gotham to his Cousin Bob in the Country' offered a light-hearted but defiantly radical account of the Town Moor meeting in the form of a poem and typical pairing of fictional regional stereotypes to explain the story. ${ }^{35}$ The preface nevertheless outlined the connection to Manchester with a radical sense of patriotism, based on customary ideas of the free-born Englishman's rights to a fair and free constitution (with echoes of William Cobbett's message in his highly popular Political Register): 'The perpetration of the Manchester Massacre aroused the indignation of every man deserving the name of Englishman. The intelligent inhabitants of this district participated in the general feeling, and were impatient to join their fellow countrymen in condemning so cruel, alarming and unprecedented an outrage. ${ }^{36}$

Most of the thousands of attendees at each demonstration that autumn would not have been active members of the democratic radical movement: it was obviously easier to attend a one-off mass meeting than commit to committee work that carried with it a high level of risk of arrest and imprisonment. These meetings fostered regional identity through narrative and emotion. At the meeting on Hunslet Moor, Leeds, on Monday 20 September 1819, the procession, 'a great number of whom were female', carried banners bearing slogans such as 'We mourn for the Murder of our Manchester Friends. ${ }^{37}$ Most of the people attending would most likely never have been to Manchester or known anyone at Peterloo, but hearing about the horrors of the yeomanry's attack on women and children connected the attendees directly in their imaginations with the workers in a similar position to theirs. Here were the shared cultural reference points that helped to shape a common working-class identity: the sense of political oppression by local as well as national authorities, exacerbated by the poverty and hunger engendered by the economic structures created by those elites. ${ }^{38}$ The working class no longer needed to have been physically attacked by the authorities to share the anger and pain of their compatriots who had.

That sense of being part of something that combined distinctive local identities with a broader regional and national movement was also enabled by the meticulously planned symbolism and ritual of these events. At the demonstration on Coalfell Hill in Carlisle in November, the town's radicals were joined by processions from the mining villages of Dalston, Wigton, Longton and Brampton, and the whole procession was led by 'committee men [who] held white wands tipped with black crape' and 'twelve Lady Radicals, neatly dressed in black, with green veils'. ${ }^{39}$ The clothing and other symbolic items and gestures enabled the crowds to express genuine mourning for the dead. ${ }^{40}$ The meetings were also a deliberate expression of local identities and customs, claiming or subverting the use of spaces from previous political usage.

Yet as with the London radicals claiming to represent the 'British metropolis, on behalf of the People of the whole Empire', these demonstrations combined distinctly local traditions and attendance with an appeal to broader layers of identity. At the first mass meeting on Coalfell Hill on 11 October, the flags included a tricolour 
of 'England, Ireland and Scotland' and a black flag exhorting the crowd to 'Abhor the Manchester Massacre'. ${ }^{41}$ Carlisle was positioned as the last English city on the main route to Scotland; Scottish and Irish immigrants made up a large proportion of its working class and, significantly, of the radical leadership, including the Scottish orator James Wemyss (known as Jimmy Weems). ${ }^{42}$ The Newcastle Town Moor meeting on the same day showed very similar features, united by mourning ritual and national as well as local emblems. The newspapers reported that 'the whole immense body marched upon the ground in solemn silence, the music playing "Scots who hae wi' Wallace bled"'. One of the leading banners, inscribed 'in memory of those who were murdered at Manchester', was adorned with 'the Rose, Thistle and Shamrock'. ${ }^{43}$ These shared symbols indicated an alternative patriotism. We must not underestimate the impact of the French and Napoleonic Wars on militarising the population, the first total war in living memory where every inhabitant of Britain was in close contact with military service, either directly as a member of the armed forces, militia or volunteers, or as a member of the family of someone who served. ${ }^{44}$ Samuel Bamford recalled in his memoirs that local veterans of the Napoleonic Wars went on to train the radicals in drilling and other military manoeuvres on the moors in the weeks leading up to Peterloo, attempting to impart a combination of orderly behaviour with brotherly solidarity. ${ }^{45}$ The barrage of anti-French propaganda issued by the government during the wars had, as Linda Colley has argued, encouraged a shared sense of British patriotism. ${ }^{46}$

But in these demonstrations, the symbolisms of unity between the nations were used in a different way, a positive identification of a shared patriotism that sought a different political system and representation from the elite and corrupt regime defended by the government. Displaying the rose, thistle and shamrock involved a skilful and conscious overturning of symbols that the government had attempted to inculcate with anti-radical meaning. As James Epstein has explained with the red cap, a radical emblem that the government and caricaturists attempted to associate with violent revolutionary republicanism but which was reclaimed by the radicals at the 1819 mass meetings as a symbol of liberty, the national symbols were reclaimed from loyalism to form a truly shared pan-regional desire for unity of the movement. ${ }^{47}$ The singing of national (and local dialect) songs moreover asserted an alternative patriotism from the Anglo-centric Britishness promoted by the government's favoured anthems of God Save the King and Rule Britannia. The government's passage of the 'Six Acts' prohibiting mass political meetings, and the subsequent trials of the radical leaders in 1820 , put an end to overt action for a decade. ${ }^{48}$ But the opponents of working-class collective action could not sustain hegemony over the meanings of political and geographical symbolism.

\section{Conclusion: From the Local to Broader Legacies}

The geographies of Peterloo were simultaneously local, regional and national in their composition and impact. The geographer Doreen Massey demonstrated that places 'are always constructed out of articulations of social relations ... which are 
not only internal to that locale but which link them to elsewhere' ${ }^{49}$ She rejected Marxist interpretations of the limitations of localism as the basis of radical politics. Theorists such as David Harvey had argued that local struggles could not reach a broader movement (or indeed class consciousness) because they were reliant on 'tradition' rather than more universal principles. He dubbed such local radicalism as 'place-bound' and therefore unable to connect with each other to form global resistance. ${ }^{50}$ Harvey classed tradition as part of nostalgia and looking back, and therefore characterised local movements as reactionary and unable to transcend the locality of place to look for more universal ideals. Massey argued that, to the contrary, radical movements can be place-based but not necessarily place-bound. Moreover, tradition and custom can be used creatively in new ways, being reinvented according to their immediate circumstances, rather than restricting participants to looking back. ${ }^{51}$

Harvey's dismissal of place-bound tradition echoes cultural theorist Svetlana Boym's definition of 'restorative nostalgia', in which people desire to bring back the past, in an attempt to recreate the 'good old days'. By contrast, Massey perhaps invokes Boym's other definition, 'reflective nostalgia', in which people accept that the past is irretrievable, but seek to recreate it in new ways in their current situations and spaces. ${ }^{52}$ David Featherstone took up Massey's challenge to Harvey's placebound radical politics in his study of London movements, particularly the supporters of John Wilkes in the 1760s and the London Corresponding Society in the 1790s. He showed how the working classes involved in these movements were place-based in their defence of their local socio-economic conditions in London, but simultaneously connected physically and ideologically with wider national and universal political movements. Their collective strength came from their deep connection to locality rather than in spite of it. ${ }^{53}$ We can apply this concept of place to the post-war radical mass platform in Manchester and the rest of the North.

The symbols and banners carried by the processions to Peterloo were tradition reinvented for the new political circumstance; expressions of locality combined with a universalist desire for parliamentary reform and an end to poverty and oppression by the elites. The cross-regional demonstrations of late 1819 were important in expressing popular discontent until the right to public meeting was severely diminished by the passing of the Six Acts. Yet as well as the memory of Peterloo being passed on, the meetings at Elland, Stockport, Newcastle and elsewhere were themselves remembered by later movements. The next waves of democratic movements used emblems from 1819 almost as secular relics that connected contemporary issues to the heritage of place. So for example, the Yorkshire Gazette reported in August 1830 how in Elland, the formation of the first political union to campaign for the Reform Bill was inaugurated with a public meeting 'marked with the mummery of exhibiting a tricoloured flag and a board (the relic we conclude of the radical meetings of 1819, as we saw one then exhibited with the same motto, "the more the cruel tyrants bind us, the more united they shall find us")'. ${ }^{54}$ The symbolic sites of protest were consciously used and developed by later radical groups: St Peter's Fields immediately became sanctified as a site of secular martyrdom, to be visited 
and crossed by political processions like pilgrimages, paying homage and reminding their followers of the repression of local and national authorities. The first 'monster meeting' of the Manchester Chartists in 1838 carried relics from Peterloo and banners referencing the massacre were an integral part of their demonstrations. ${ }^{55}$ They drew directly on the legacy of Peterloo both to prove their own legitimacy within a longer radical tradition and also to develop the narrative of continued government repression of legal meetings for parliamentary reform.

Joseph Cozens's recent work on the memorialisation of Peterloo demonstrates the long-lasting yet mutable legacies that later political groups made of the event as part of their own campaigns, from the veneration of elderly survivors by the Victorian Liberal Party (notably the Failsworth veterans during the 1884 Reform Bill agitation) to the present-day calls for a memorial on the site of the massacre. ${ }^{56}$ Peterloo matters today because it was both a local and a national event. The locality itself and the possibility that ancestors may have attended the meeting has a deep connection with today's inhabitants of Manchester and the surrounding towns, while the broader message of Peterloo - that the government and local authorities violated the right of people to meet peacefully to campaign for political reform - maintains a universality that connects the local with the global.

\section{Notes}

1 Donald Read, Peterloo: The Massacre and its Background (Manchester, Manchester University Press, 1958), pp. 224-6; Robert Poole, " "By the Law or By the Sword": Peterloo Revisited', History, 91:302 (2006), 254-76; Robert Poole (ed.), Return to Peterloo (Manchester, Manchester Centre for Regional History, 2014).

2 For example, John Gardner, Poetry and Popular Protest: Peterloo, Cato Street and the Queen Caroline Controversy (Basingstoke, Palgrave Macmillan, 2011); Alison Morgan, Ballads and Songs of Peterloo (Manchester, Manchester University Press, 2018).

3 Manchester October, 23 October 1819; F. A. Bruton, 'Three Accounts of Peterloo', Bulletin of the John Rylands Library, 5:3-4 (April-October 1919), 254-95; Robert Walmsley, Peterloo: the Case Reopened (Manchester, Manchester University Press, 1969), pp. 178-9.

4 Michael Bush, The Casualties of Peterloo (Lancaster, Carnegie Press, 2005).

5 Robert Poole, 'The March to Peterloo: Politics and Festivity in Late Georgian England', Past \& Present, 192 (2006), 109-53; Malcolm Chase, 1820: Disorder and Stability in the United Kingdom (Manchester, Manchester University Press, 2013), p. 12.

6 Poole, 'The March to Peterloo', 125-7.

7 Calculations of distances made plotting the addresses listed in British Library, 601.aa.9.(1), Anon, Peterloo Massacre, Containing a Faithful Account of the Events which Preceded, Accompanied, and Followed the Fatal Sixteenth of August, 1819 ... Edited by an Observer (Manchester, J. Wroe, 1819), p. 190, and QGIS mapping software; Katrina Navickas, Protest and the Politics of Space and Place, 1789-1848 (Manchester, Manchester University Press, 2015), p. 112.

8 Navickas, Protest and the Politics of Space and Place, p. 73. 
9 Poole, 'The March to Peterloo', 113.

10 Charles Tilly, Popular Contention in Great Britain, 1758-1834 (Cambridge, MA, Harvard University Press, 1995), p. 81.

11 See Malcolm Chase, 'The Popular Movement for Parliamentary Reform in Provincial Britain during the 1860s', Parliamentary History, 36:1 (2017), 14-30; Tom Scriven, Popular Virtue: Continuity and Change in Radical Moral Politics, 1820-70 (Manchester, Manchester University Press, 2017), pp. 2-3.

12 Poole, 'By the Law or By the Sword', 266, citing The National Archives (hereafter TNA), HO 79/3/396, Hobhouse to Norris, 16 June 1819.

13 London Metropolitan Archives, PS/NEW/01, East Brixton and Southwark Magistrates' minute book 1810-1819, 20 August 1819.

14 TNA, HO 41/4, Home Office Disturbance Entry book, p. 257, Hobhouse to Earl of Derby, 24 February 1819; HO 41/4, p. 320, Hobhouse to Norris, 3 July 1819; Leeds Mercury, 24 July 1819; Poole, 'By the Law or By the Sword', 267.

15 Read, Peterloo, p. 132.

16 Joseph Cozens, 'The Making of the Peterloo Martyrs, 1819 to the Present', in Quentin Outram and Keith Laybourn (eds), Secular Martyrdom in Britain and Ireland From Peterloo to the Present (Basingstoke, Palgrave, 2018), p. 33.

17 The Diaries of Absalom Watkin, a Manchester Man, 1787-1861, ed. Magdalen Goffin (Sutton Publishing, Stroud, 1993), p. 43.

18 Parliamentary Papers, lxi, Papers Relating to the Internal State of the Country Presented to Both Houses of Parliament ... November 1819 (London, London Gazette Office, 1819), pp. 35-6.

19 Ibid., pp. 35-6; Hull Advertiser, 18 September 1819.

20 Papers Relating to the Internal State of the Country, 23 November 1819; Cumbria Record Office, Carlisle, D/LONS/L2/67, Lord Lowther's diary, 1819.

21 Yorkshire Gazette, 11 September 1819. Further examples of shots being fired into the houses of targets, and incendiarism, are recorded in Bolton Archives, ZZ 530/2, Holden diaries, 1819; Norris to Sidmouth, 10 November 1819, cited in Papers Relating to the Internal State of the Country, pp. 61-2; Westmorland Gazette, 20 November 1819.

22 Cumbria Record Office, Carlisle, D/LONS/L2/67, Lord Lowther's diary, 1819.

23 Westmorland Gazette, 6 May 1820.

24 West Yorkshire Archives Service, Calderdale, SH:7/ML/E/3, H. Whitbread, transcript of the diary of Anne Lister, 1819, p. 156: www.annelister.co.uk/wp-content/uploads/annelister-diary-archive-1819-08-16.jpg (accessed 9 August 2018).

25 Navickas, Protest and the Politics of Space and Place, p. 89; Manchester Observer, 9 October 1819.

26 Carlisle Patriot, 16 October 1819; Yorkshire Gazette, 25 September 1819.

27 TNA, TS 25/2035, fo. 174, Treasury Solicitor's papers, law officers' opinion book, 2 September 1819.

28 Morning Post, 23 August 1819.

29 Iain McCalman, Radical Underworld: Prophets, Revolutionaries and Pornographers in London, 1795-1840 (Cambridge, Cambridge University Press, 1988), pp. 134-5. 
30 Examiner, 29 August 1819.

31 London Metropolitan Archives, PS/NEW/01, East Brixton and Southwark Magistrates' minute book 1810-1819, 25 August 1819.

32 Morning Post, 23 August 1819.

33 Leeds Mercury, 13 November 1819; West Yorkshire Archives Service, Leeds, WYL 250/6/2/box 2, West Riding lieutenancy correspondence, Hardy to Lascelles, 4 November 1819.

34 E. P. Thompson, The Making of the English Working Class, 2nd edn (Harmondsworth, Penguin, 1968), p. 758.

35 John Rylands Library, University of Manchester, R228953, Radical Monday: a Letter from Bob in Gotham to his Cousin Bob in the Country (Newcastle, 1821). One cannot help but trace the legacy of these literary form of regional stereotypes of the 'everyman' to the 'likely lads' Bob and Terry in the 1960s TV series The Likely Lads and its 1970s sequel Whatever Happened to the Likely Lads? See Neville Kirk (ed.), Northern Identities (Aldershot, Routledge, 2000); Adrian Green and A. J. Pollard (eds), Regional Identities in North-East England, 1300-2000 (Woodbridge, Boydell Press, 2000), p. 195. See also the Rochdale characters Tummus and Mary by Tim Bobbin, and the Oldham series of broadside ballads, Jone O'Grinfilt, the latter of which had a Peterloo related version: Katrina Navickas, 'Theaw Kon Ekspect No Mooar Eawt ov a Pig thin a Grunt': Searching for the Radical Dialect Voice in Industrial Lancashire and the West Riding, 1798-1819', in J. Kirk, A. Noble and M. Brown (eds), United Islands?: The Languages of Resistance (London, Pickering \& Chatto, 2012), pp. 181-94.

36 John Rylands Library, University of Manchester, R228953, Radical Monday: a Letter from Bob in Gotham to his Cousin Bob in the Country (Newcastle, 1821), p. i.

37 Hull Advertiser, 24 September 1819.

38 Thompson, The Making of the English Working Class, pp. 756-60.

39 Carlisle Patriot, 6 November 1819.

40 For a meeting at Haberghameaves, Burnley, see TNA, PL 27/9, examinations of William Chaffers and Joseph Greenhaulgh, November 1819.

41 Carlisle Patriot, 16 October 1819.

42 June Barnes, 'The Trade Union and Radical Activities of the Carlisle Handloom Weavers', Transactions of the Cumberland and Westmorland Antiquarian and Archaeological Society, 78 (1978), 149-62.

43 Globe, 15 October 1819.

44 Gordon Pentland, 'Militarization and Collective Action in Great Britain', in Michael T. Davis (ed.), Crowd Actions in Britain and France from the Middle Ages to the Modern World (London, Palgrave Macmillan, 2015), pp. 179-92.

45 Samuel Bamford, Passages in the Life of a Radical (London, 1849), ch. 24: http://geraldmassey.org.uk/bamford/c_radical_(8).htm\#XXIV (accessed 28 September 2018).

46 Linda Colley, Britons: Forging the Nation (New Haven, Yale University Press, 1992), pp. 283-308.

47 James Epstein, 'Understanding the Cap of Liberty: Symbolic Practice and Social Conflict in Early Nineteenth-Century England', Past \& Present, 122 (1989), 75-118 (at p. 75). 
48 Katrina Navickas, Protest and the Politics of Space and Place, 1789-1848 (Manchester, Manchester University Press, 2015), pp. 98-9.

49 Doreen Massey, 'Places and their Pasts', History Workshop Journal, 39 (1995), 182-92 (at p. 183).

50 David Harvey, The Condition of Postmodernity: An Enquiry into the Origins of Cultural Change (Oxford, Blackwell, 1989), p. 303.

51 Massey, 'Places and their Pasts', 184.

52 Svetlana Boym, The Future of Nostalgia (Michigan, Basic Books, 2001), pp. 49-51. Thanks to Sarah Lloyd for this reference.

53 David Featherstone, 'Towards the Relational Construction of Militant Particularisms: or Why the Geographies of Past Struggles Matter for Resistance to Neoliberal Globalisation', Antipode, 37:2 (2005), 250-71 (at p. 262).

54 Yorkshire Gazette, 28 August 1830.

55 Manchester Guardian, 26 September 1838; Read, Peterloo, p. 206; Paul A. Pickering, Chartism and the Chartists in Manchester and Salford (Basingstoke, Macmillan Press, 1995), p. 35.

56 Cozens, 'The Making of the Peterloo Martyrs', p. 32. 
